\title{
Modulation of Activity of the Striatal Dopaminergic System During the Hibernation Cycle
}

\author{
Thomas S. Kilduff, S. Scott Bowersox, Kym F. Faull, Lori Zeller-DeAmicis, Carolyn M. Radeke, ${ }^{1}$ Roland D. \\ Ciaranello, H. Craig Heller, ${ }^{1}$ Jack D. Barchas, and William C. Dement \\ Departments of Psychiatry and 'Biological Sciences, Stanford University School of Medicine, Stanford, California 94305
}

\begin{abstract}
To evaluate how the activity of a well-established neurotransmitter pathway is modulated by a behavioral state, ${ }^{3} \mathrm{H}$ spiperone binding sites and dopamine (DA) and DA metabolite concentrations were measured in the striata of ground squirrels in 5 phases of the hibernation cycle. Whereas levels of striatal DA and its deaminated metabolite DOPAC did not change significantly, the concentrations of the $O$-methylated-deaminated metabolite, homovanillic acid (HVA), decreased in all phases of hibernation relative to euthermia. Striatal ${ }^{3} \mathrm{H}$-spiperone binding sites declined across the hibernation cycle in parallel with the reduction of HVA concentration; receptor binding affinity was unchanged by arousal state. In conjunction with previously reported findings, these results are consistent with the hypothesis that hibernation is associated with a down-regulation of the postsynaptic $D_{2}$ receptors secondary to increased extracellular DA concentration and reduced DA degradation.
\end{abstract}

Mammalian hibernation is characterized by down-regulation of multiple physiological systems (Heller et al., 1986). These physiological adjustments at the systemic level are accompanied by a general depression of CNS activity, as evidenced by decreased responsiveness to external stimuli (Strumwasser, 1959a), attenuated cortical EEG activity (Strumwasser, 1959b; South et al., 1969; Shtark, 1970), and reduced sensitivity to neurochemical stimulation (Beckman and Stanton, 1982). Although there have been no systematic studies of the firing rate of single cells during the hibernation cycle to this date, it is probable that unit activity in most, if not all, brain regions is greatly attenuated during entrance to and during deep hibernation. Under such conditions of "functional deafferentation," the development of an up-regulation or supersensitivity of postsynaptic receptors might be expected to occur.

Recently, analysis of perfusates extracted from the striatum of ground squirrels during hibernation revealed significantly increased levels of both free and conjugated dopamine (DA), decreased concentrations of D $\Lambda$ metabolites homovanillic acid (HVA) and 3,4-dihydroxyphenylacetic acid (DOPAC), and the appearance of the unusual $O$-methylated-deaminated metabolite homovanillyl alcohol (HVOH), also referred to as 3-me-

\footnotetext{
Received Nov. 26, 1986; revised Mar. 23, 1987; accepted Mar. 23, 1987.

We thank Lauri Haak and Debby Egner for technical assistance. This work was supported by NSF Grant BNS 8216918 (to H.C.H.), NIH MH23861 (to J.D.B.) and NIH NS 23724 and MH05804 (to W.C.D.).

Correspondence should be addressed to Dr. Kilduff, Sleep Research Center, Department of Psychiatry, Stanford University School of Medicine, Stanford, CA 94305.

Copyright (c) 1987 Society for Neuroscience $0270-6474 / 87 / 092732-05 \$ 02.00 / 0$
}

thoxy-4-hydroxyphenethanol (MOPET) (Salzman et al., 1985). On the basis of these findings, Salzman et al. concluded that during hibernation higher extracellular levels of DA exist in the striatum and that DA degradation is shifted away from the aldehyde dehydrogenase route to metabolism by alcohol dehydrogenase. Moreover, it was suggested that the higher extracellular DA levels and the appearance of a conjugated form of DA may serve to prevent the development of receptor supersensitivity that might otherwise occur as a consequence of the prolonged periods of reduced neural activity characteristic of hibernation.

The purpose of the present study was to assess whether a supersensitivity of postsynaptic striatal dopamine $D_{2}$ receptors is present during hibernation, as Salzman and colleagues postulated. To gain a more complete insight into the modulation of activity that occurs in a well-established neurotransmitter pathway during hibernation, an analysis of the concentrations of striatal DA and its metabolites was undertaken in parallel with measurement of receptor binding parameters. Our results indicate that $D_{2}$ receptors decrease in concentration across the hibernation cycle as a consequence of increascd extraccllular DA and decreased extracellular DA degradation.

\section{Materials and Methods}

Animals. Golden-mantled ground squirrels (Citellus lateralis) were implanted with abdominal telemeters (Mini-Mitter Co., Sunriver, OR) to monitor body temperature $\left(T_{\mathrm{b}}\right)$ continuously during the hibernation season. Animals were placed in a constant-temperature environment at $5^{\circ} \mathrm{C}$ under a light-dark $12: 12$ photoperiod. Four animals were decapitated between $1200-1600 \mathrm{hr}$ during each of 5 phases of the hibernation cycle: euthermia $\left(T_{\mathrm{b}}=37^{\circ} \mathrm{C}\right)$; entrance to hibernation $\left(T_{\mathrm{b}}=20^{\circ} \mathrm{C}\right)$; day 1 of deep hibernation $\left(T_{\mathrm{b}}<8^{\circ} \mathrm{C}\right)$; days 4 or 5 of deep hibernation $\left(T_{\mathrm{b}}<\right.$ $\left.8^{\circ} \mathrm{C}\right)$; and arousal $\left(T_{\mathrm{b}}=20^{\circ} \mathrm{C}\right)$. The brains were removed, dissected into subregions, and frozen on dry ice. Tissue samples were weighed while still frozen and stored at $-80^{\circ} \mathrm{C}$ until they were analyzed $(<2$ months for $\mathrm{D}_{2}$ receptors and 6 months for biogenic amines). One striatum from each animal was assigned to the receptor study and the contralateral striatum from each animal to analysis for biogenic amines.

Biogenic amine analysis. Tissue samples (typically $60 \mathrm{mg}$ ) were prepared for analysis by sonication in 7 vol $0.4 \mathrm{~N} \mathrm{HCl}$ at $0^{\circ} \mathrm{C}$ containing a mixture of internal standards (caffeic acid and dihydroxybenzylamine [DHBA] ) and centrifuged $(2000 \times g, 15 \mathrm{~min})$. The pellet was rehomogenized in $5 \mathrm{vol} \mathrm{HCl}$ and recentrifuged; the supernatants were pooled. HVA was chromatographically separated from other compounds by injection of the recentrifuged supernatant $(5 \mu \mathrm{l})$ onto a reverse-phase microbore high-pressure liquid chromatography (HPLC) system (column $\mathrm{C}_{18}, 3 \mu, 10 \mathrm{~cm} \times 1.0 \mathrm{~mm}$ i.d.; eluant, $0.2 \mathrm{M} \mathrm{NaH}_{2} \mathrm{PO}_{4}$ containing $50 \mathrm{mg} /$ liter EDTA, $0.005 \%$ sodium octyl sulfate, and $5 \% \mathrm{CH}_{3} \mathrm{CN}$, pH 4.2 , at $100 \mu \mathrm{l} / \mathrm{min}$ ) (Caliguri et al., 1985) and detected amperometrically (BAS TL-8A glassy carbon electrode, $\mathrm{Ag} / \mathrm{AgCl}$ reference, $0.85 \mathrm{~V}$ ). Quantitation was achicved using caffeic acid as the internal standard. The catecholamines and DOPAC in the remaining supernatant were adsorbed to alumina at $\mathrm{pH} 8.6(1 \mathrm{ml}$, Tris- $\mathrm{HCl}, 3 \mathrm{M})$ and then desorbed 
DAY 1 HIBERNATION: STRIATUM

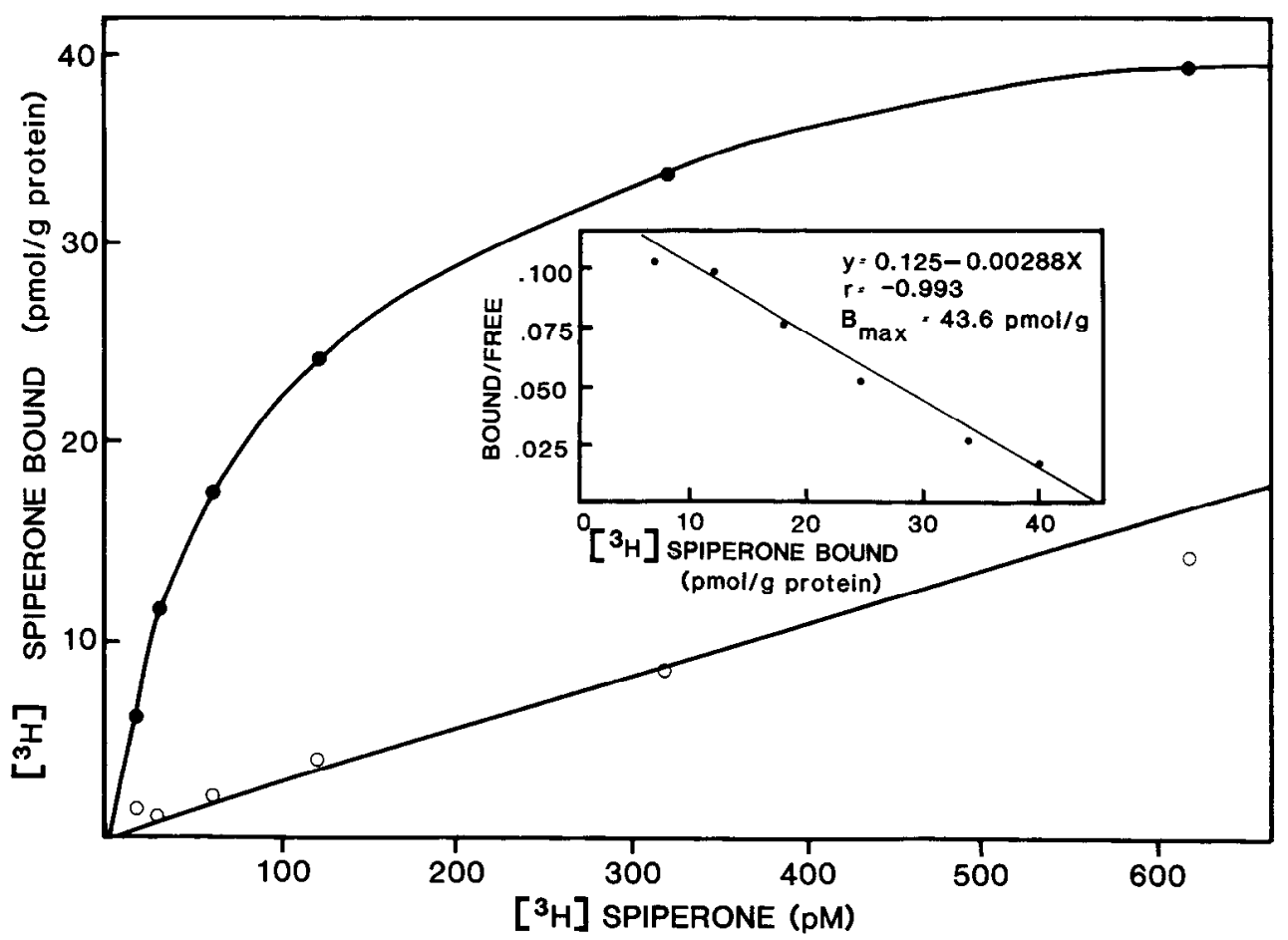

Figure 1. Saturation isotherm for ${ }^{3} \mathrm{H}-$ spiperone binding to striatum from a ground squirrel sacrificed on day 1 of hibernation (e, specific binding; 0 , nonspecific binding). Inset, Scatchard plot calculated from these data. with $\mathrm{HClO}_{4}(30 \mu \mathrm{l}, 0.4 \mathrm{M})$ and chromatographically separated by injection of the perchlorate solution onto a reverse-phase microbore HPLC system, the same as described above with the eluant containing sodium octyl sulfate $(99 \mathrm{mg} / \mathrm{liter})$ and $0.4 \%$ acetone at $\mathrm{pH} 3.2$. The compounds were detected amperometrically $(0.85 \mathrm{~V})$, and quantitation was achieved using DHBA as the internal standard (Mefford, 1981).

Receptor hinding studies. Tissues were homogenized with a Polytron tissue grinder in $6 \mathrm{ml}$ of ice-cold $50 \mathrm{~mm} \mathrm{Na-K}$ phosphate buffer, $\mathrm{pH}$ 7.4. Homogenates were centrifuged $\left(14,000 \times \mathrm{g}, 15 \mathrm{~min}, 4^{\circ} \mathrm{C}\right)$, and pellets were washed twice by resuspension and recentrifugation. The final pellet was resuspended in $10 \mathrm{ml}$ of $50 \mathrm{~mm}$ Tris- $\mathrm{HCl}$ buffer $(\mathrm{pH} 7.4$ at $30^{\circ} \mathrm{C}$ ) containing $4 \mathrm{~mm} \mathrm{MgSO}_{4}, 1 \mathrm{~mm}$ EDTA, and $100 \mathrm{~mm} \mathrm{NaCl}$, and then preincubated for $30 \mathrm{~min}$ at $30^{\circ} \mathrm{C}$ to destroy endogenous DA. $\mathrm{D}_{2}$ receptors were measured by ${ }^{3} \mathrm{H}$-spiperone $(22.0 \mathrm{Ci} / \mathrm{mmol}$; New England Nuclear) binding in the presence of $40 \mathrm{~nm}$ cinanserin to mask 5-HI receptors (optimal cinanserin concentration was determined in preliminary competition studies). Nonspecific binding was defined as that remaining in the presence of $300 \mathrm{nM}$ butaclamol. Total binding was measured in triplicate and nonspecific binding in duplicate. Binding was initiated by adding $900 \mu \mathrm{l}$ of tissue suspension (approximately 0.21 mg protein) to tubes containing receptor ligands made up in $1 \mathrm{mM} \mathrm{HCl}$; final assay volume was $1 \mathrm{ml}$. Tissues were incubated for $20 \mathrm{~min}$ at $30^{\circ} \mathrm{C}$ with 6-7 increasing concentrations of ${ }^{3} \mathrm{H}$-spiperone; final concentrations ranged from 15 to $600 \mathrm{pM}$. Incubation was terminated by rapid vacuum filtration with subsequent rinsing (ice-cold $50 \mathrm{~mm}$ Tris- $\mathrm{HCl}, \mathrm{pH} \mathrm{7.4,} \mathrm{at}$ $4^{\circ} \mathrm{C}$ ) over glass-fiber filters (Whatman $\mathrm{GF} / \mathrm{C}$ ) presoaked in $0.1 \%$ polyethylinimine (Sigma). Quantitation of receptor parameters was by Scatchard analysis of radioligand binding data using the weighted nonlinear, least-squares curve-fitting program LIGAND, modified for use on the IBM-XT. Data were analyzed according to both 1- and 2-site-binding models. The statistical goodness-of-fit to computed curves was defined by the weighted residual variance. The binding model best describing the distribution of a given data set was determined by statistical comparisons of residual variances ( $F$ test). Group comparisons of binding data were 2-tailed $t$ tests corrected for multiple contrasts (Games, 1977).

\section{Results}

\section{Receptor binding}

${ }^{3} \mathrm{H}$-spiperone binding to squirrel striatum was linear in the range of $1.0-1.5 \mathrm{mg}$ tissue/tube and reached equilibrium after $20 \mathrm{~min}$ incubation. Equilibrium was facilitated by the presence of 100 mm $\mathrm{NaCl}$ as described previously (Usdin et al., 1980). As found in other rodent species, cinanserin $/{ }^{3} \mathrm{H}$-spiperone competition curves in the presence of $4 \mathrm{~mm} \mathrm{MgSO}_{4}$ and $100 \mathrm{~mm} \mathrm{NaCl}$ were biphasic (Boehme and Ciaranello, 1982; Hamblin et al., 1984), with a plateau between 0.1 and $500 \mathrm{nM}$. A concentration of 40 nM cinanserin was thus chosen to block 5-HT receptors.

A typical saturation isotherm and Scatchard plot are illustrated in Figure 1. All binding data were best described by a 1 -site-binding model. Scatchard plots were uniformly linear, with regression coefficients ranging from 0.94 to 0.99 . Further evidence of receptor homogeneity was provided by Hill analyses of binding data, which yielded coefficients near unity $(0.92-$ 1.10).

Receptor binding affinity $\left(K_{d}\right)$ did not differ among the 5 groups (Table 1); however, the number of ${ }^{3} \mathrm{H}$-spiperone binding sites $\left(B_{\max }\right)$ varied consistently throughout the hibernation cycle (Fig. 2 ). The $B_{\max }$ values of day 1 and day $4 / 5$ of deep hibernation were significantly reduced with respect to the euthermic $B_{\max }$ values $(p<0.01)$. $B_{\max }$ values of both entrance and arousal

Table 1. Parameters of ${ }^{3} \mathrm{H}$-spiperone binding to striata from ground squirrels in different phases of hibernation

\begin{tabular}{lcc} 
Phase of cycle & $\begin{array}{l}K_{\mathrm{d}} \\
(\mathrm{pM})\end{array}$ & $\begin{array}{l}B_{\max } \\
(\mathrm{pmol} / \mathrm{g} \text { protein) }\end{array}$ \\
\hline Euthermia & $104.0 \pm 4.7$ & $113.3 \pm 3.8$ \\
Entrance & $117.5 \pm 1.2$ & $90.4 \pm 8.4$ \\
Hibernation-Day 1 & $91.6 \pm 10.9$ & $62.9 \pm 7.4^{a}$ \\
Hibernation-Day 4/5 & $76.8 \pm 11.6$ & $77.0 \pm 5.6^{a}$ \\
Arousal & $102.4 \pm 10.4$ & $83.6 \pm 12.2$
\end{tabular}

Values are means \pm SEM.

${ }^{a} p<0.01$ compared with the euthermic (nonhibernation) condition. Corrected for multiple contrasts as per Games (1977). 


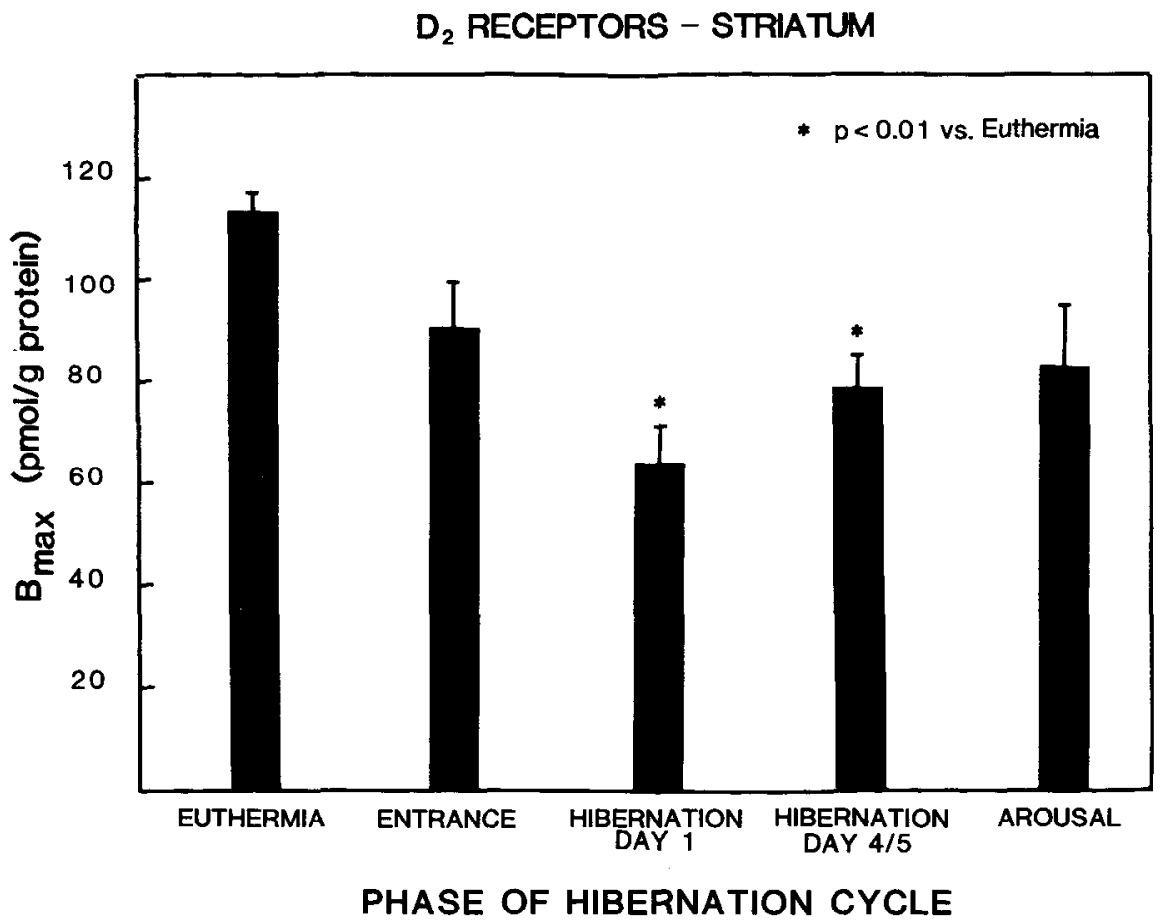

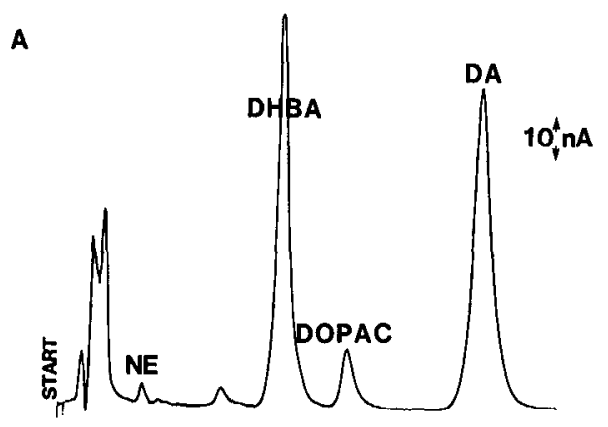

$\mathbf{B}$

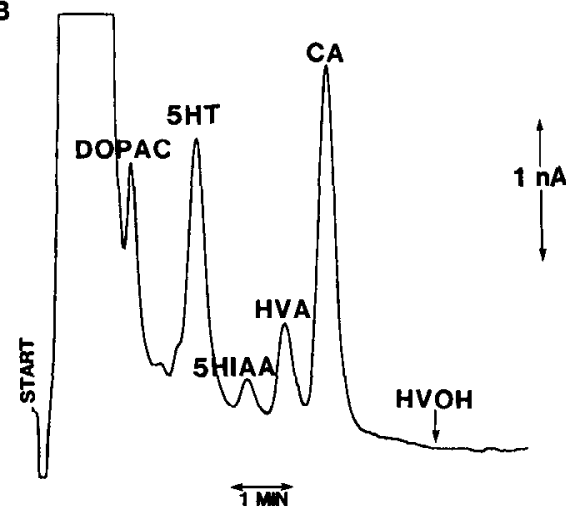

Figure 3. Chromatography of extracts of striata from ground squirrels sacrificed during 2 stages of hibernation. $A$, Chromatogram of the catecholamine extract from an animal entering hibernation. $N E$, norepinephrine; $D H B A$ (internal standard), 3,4-dihydroxybenzylamine; $D O$ $P A C, 3,4$-dihydroxyphenylacetic acid; $D A$, dopamine. $B$, Chromatogram of the unpurified tissue extract from an animal arousing from hibernation. 5- $H T$, serotonin; 5-HIAA, 5-hydroxyindoleacetic acid; $H V A$, homovanillic acid; $C A$ (internal standard), caffeic acid; $H V O H$, homovanillyl alcohol. groups were intermediate between the euthermic and hibernation values.

\section{Biogenic amine analysis}

Analysis of the homologous contralateral striata did not reveal any systematic changes in tissue concentrations of DA or DOPAC across the hibernation cycle. Figure 3 illustrates a typical chromatogram identifying peaks corresponding to specific biogenic amines. Although the response obtained for authentic HVOH suggested a conservative estimate of the sensitivity for the detection of this metabolite in tissue extracts to be $70 \mathrm{ng}$ / gm (typically, $4 \mathrm{ng} / \mathrm{sample}$ ), we were unable to identify $\mathrm{HVOH}$ in any of the 20 samples. In contrast, the levels of HVA were significantly reduced in all phases of the hibernation cycle with respect to euthermia (Fig. 4).

\section{Discussion}

The objective of the present study was to evaluate whether striatal ${ }^{3} \mathrm{H}$-spiperone binding sites increased in number $\left(B_{\max }\right)$ during hibcrnation, as would be expected under conditions of "functional deafferentation," or are "protected" from supersensitivity, as suggested by Salzman and colleagues (1985). Our data (Fig. 2) demonstrate yet another result: ${ }^{3} \mathrm{H}$-spiperone binding sites clearly decrease in concentration across the hibernation cycle. During stable deep hibernation, this reduction reaches statistical significance. During the transitional stages (entrance to and arousal from hibernation), $B_{\max }$ values intermediate between those observed in euthermia and deep hibernation are present.

The concentration of the DA metabolite HVA also decreased across the hibernation cycle in parallel with reduced receptor concentrations (Fig. 4). Values in all 4 experimental groups underwent significant decreases relative to euthermic values. In contrast, the concentrations of DA itself and the other major DA metabolite DOPAC did not significantly change. These data 


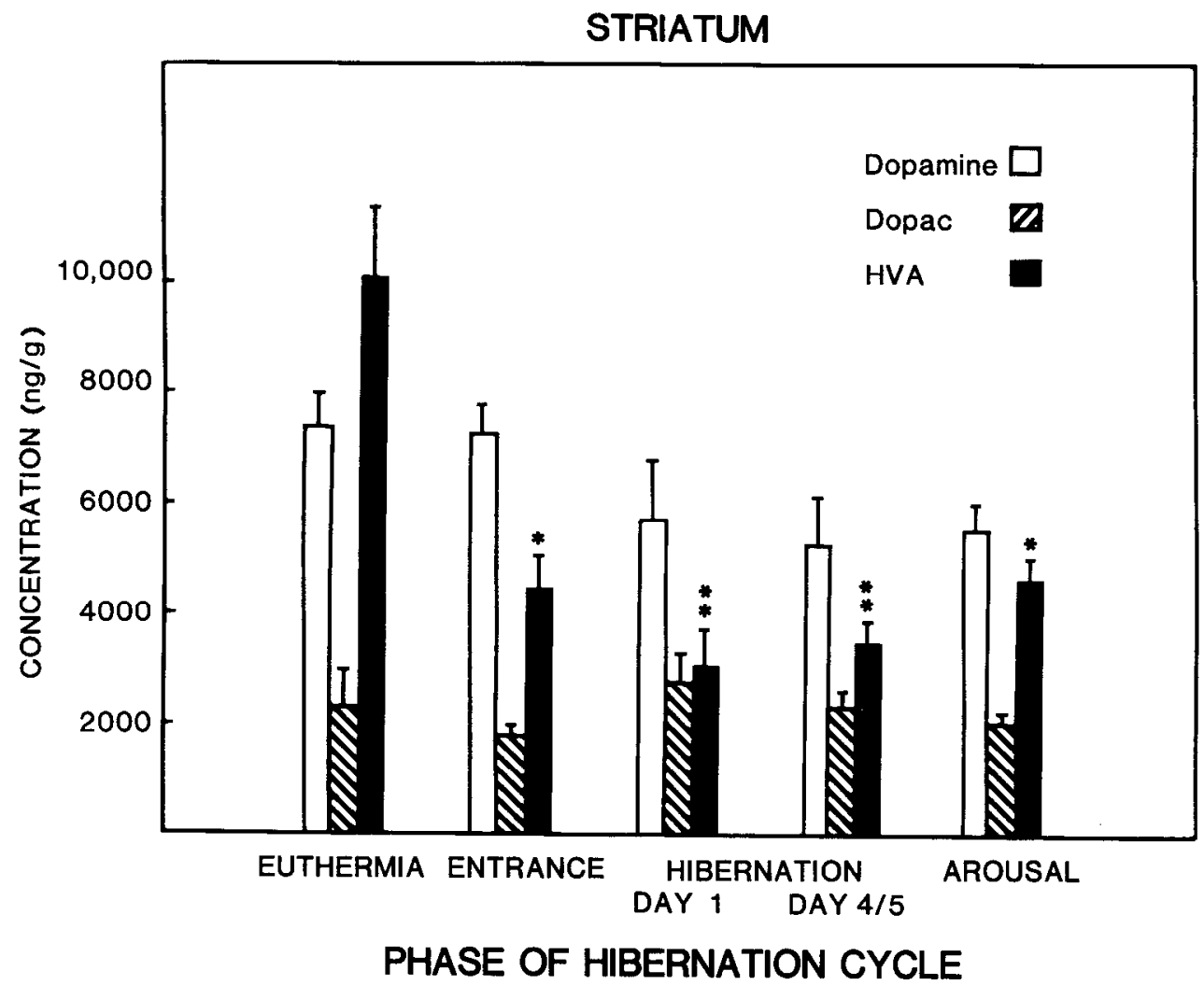

Figure 4. Concentrations of DA, DOPAC, and HVA in striatal homogenates of ground squirrels sacrificed across the hibernation cycle $\left(^{*}\right.$, $p<0.05 ;{ }^{* *}, p<0.01$ ). suggest that the degradation of DA is shifted away from HVA during deep hibernation to somc other mode of metabolism.

In an analysis of perfusates obtained from the striatum of squirrels, Salzman et al. (1985) also documented decreased HVA levels during hibernation. However, in these perfusates, DA levels were also significantly elevated, DOPAC was not detectable and an atypical metabolite, MOPET, was detected during hibernation. We were unable to confirm any of these latter findings (Fig. 4). Although both studies employed HPLC with electrochemical detection, Salzman et al. analyzed striatal perfusates collected in vivo, whereas our study was a post-mortem analysis of striatal homogenates. Thus, our results are measurements of total tissue concentrations of DA and its metabolites, whereas Salzman et al. presumably reported data obtained from extracellular fluid in the striatum.

Taken together, the results of Salzman et al. (1985) and the present study suggest the following interpretation: (1) Although the total tissue concentration of DA in the striatum does not change across the hibernation cycle, a greater proportion of DA is to be found extracellularly during hibernation than during euthermia; (2) the net metabolism of DA to DOPAC is not significantly changed during hibernation, although extracellular DOPAC decreases; (3) the total tissue concentration of HVA is decreased despite increased extracellular DA levels and, possibly, the appearance of a conjugated form of DA (Salzman et al., 1985). This decrease of extracellular HVA is consistent with the idea of a shift of metabolism of the intermediate dopamine metabolite, 3-methoxy-4-hydroxy-phenylacetaldehyde, from aldehyde dehydrogenase to alcohol dehydrogenase (Salzman et al., 1985). However, the failure to detect significant quantities of the alcohol dehydrogenase metabolite $\mathrm{HVOH}$ in the present study challenges this interpretation.

The decreased levels of striatal $\mathrm{D}_{2}$ receptors during hiber- nation may be related to the increased extracellular DA levels described previously for this state (Salzman et al., 1985). Rather than serving to "protect" postsynaptic striatal receptors from developing supersensivity due to "functional deafferentation" during hibernation, increased extracellular DA may actually result in $\mathrm{D}_{2}$ receptor down-regulation (Fig. 2). Alternatively, $\mathrm{D}_{2}$ receptors may be degraded but not replaced during hibernation because of decreased anabolic activity. However, the fact that the value for $\mathrm{D}_{2}$ receptor concentration during arousal was intermediate between the hibernating and euthermia levels suggests rapid initiation of receptor synthesis, if the latter hypothesis is correct.

The mechanism by which extracellular DA is elevated in hibernation remains to be elucidated. At least 2 possibilities exist: Either presynaptic DA release is increased during hibernation or the degradation of extracellular DA is decreased substantially greater than any decrement in presynaptic DA release. The former possibility is unlikely due to the profound depression of electroencephalographic activity documented in various brain regions during hibernation (Shtark, 1970). To substantiate whether the striatum is truly subjected to functional deafferentation during hibernation as expected, it would be desirable to record from cells, for example, in the nigrostriatal system across the hibernation cycle. Because the location of the source of the $\mathrm{D}_{2}$ receptors within the striatum is still unclear (Trugman et al., 1986), selection of the precise cells to record is difficult. It would also be useful to measure striatal DA release directly using in vivo voltammetry, as has been done in freely moving euthermic animals (Brazell et al., 1984; Marsden et al., 1984). Furthermore, measurement of the presumed presynaptic $D_{1}$ receptor would provide an indirect index of DA release in this state (Seeman, 1980).

The latter possibility of decreased DA metabolism is a more 
likely explanation for the increased extracellular DA levels during hibernation. The decreased levels of HVA found in the current study as well as that by Salzman et al. are consistent with this hypothesis. The proposed shunting of DA degradation from aldehyde dehydrogenase to alcohol dehydrogenase could best be addressed by direct measurement of the activities of these enzymes in the euthermic and hibernating states. Our results do not support the shunting hypothesis because of the failure to detect significant quantities of the metabolite MOPET during hibernation.

These changes in striatal DA metabolism and ${ }^{3} \mathrm{H}$-spiperone binding may reflect alteration in endogeneous opiates during the hibernation cycle. It is now well established that opiates affect DA release (Chesselet et al., 1981; Yonehara and Clouet, 1984; Broderick, 1985) and turnover (Yonehara and Clouet, 1984) in several species. Alteration of endogenous opiate levels in the CNS during hibernation has been implicated by the observations that hibernating animals administered morphine do not develop physical dependence (Beckman et al., 1981), whereas the abstinence syndrome develops in nonhibernating squirrels at all times of year (Beckman et al., 1982). Whole brain levels of met-enkephalin have been found to undergo a 2-fold increase in hibernating ground squirrels (Kramarova et al., 1983), whereas leu-enkephalin does not change significantly. Last, intracerebroventricular infusions of naloxone cause a dose-dependent reduction of hibernation bout length (Beckman and Llados-Eckman, 1985). These observations are suggestive of widespread alterations of the activity of neurotransmitter pathways, as well as neural metabolism (Kilduff et al., 1982), during the hibernating state.

\section{References}

Beckman, A. L., and C. Llados-Eckman (1985) Antagonism of brain opioid peptide action reduces hibernation bout duration. Brain Res. 328: 201-205.

Beckman, A. L., and T. L. Stanton (1982) Properties of the CNS during hibernation. In The Neural Basis of Behavior, A. L. Beckman, ed., pp. 19-45, Spectrum, New York.

Beckman, A. L., C. Llados-Eckman, T. L. Stanton, and M. W. Adler (1981) Physical dependence on morphine fails to develop during the hibernating state. Science 212: 1527-1529.

Beckman, A. L., C. Llados-Eckman, T. L. Stanton, and M. W. Adler (1982) Seasonal variation of morphine physical dependence. Life Sci. 30: 147-154.

Boehme, R. E., and R. D. Ciaranello (1982) Genetic control of dopamine and serotonin receptors in brain regions of inbred mice. Brain Res. 266: 51-65.

Brazell, M. P., N. T. Maidment, and C. A. Marsden (1984) Microelectrodes for in vivo neuroelectrochemistry. In Charge and Field Effects in Biosystems, M. J. Allen and P. N. R. Usherwood, eds., pp. 499505, Abacus Press, Tunbridge Wells, Kent, U.K.

Broderick, P. A. (1985) In vivo electrochemical studies of rat striatal dopamine and serotonin relcasc after morphinc. Life Sci. 36: 2269 2275.

Caliguri, E. J., P. Capella, L. Bottari, and I. N. Mefford (1985) Highspeed microbore liquid chromatography using $\mathrm{C} 18$ packing material. Anal. Neurochem. 57: 2423-2425.

Chesselet, M. F., A. Cheramy, T. D. Reisine, and J. Glowinski (1981) Morphine and $\delta$-opiate agonists locally stimulate in vivo dopamine release in cat caudate nucleus. Nature $291: 320-322$.

Games, P. A. (1977) An improved $t$ table for simultaneous control on $g$ contrasts. J. Am. Stat. Assoc. 72: 531-534.

Hamblin, M. W., S. E. Leff, and I. Creese (1984) Interactions of agonists with D-2 dopamine receptors: Evidence for a single receptor population existing in multiple agonist affinity-states in rat striatal membranes. Biochem. Pharmacol. 33: 877-887.

Heller, H. C., X. J. Musacchia, and L. C. H. Wang (1986) Living in the Cold, Physiological and Biochemical Adaptations, Elsevier, New York.

Kilduff, T. S., F. R. Sharp, and H. C. Heller (1982) [ $\left.{ }^{14} \mathrm{C}\right] 2$-deoxyglucose uptake in ground squirrel brain during hibernation. J. Neurosci. 2: 143-157.

Kramarova, L. I., S. H. Kolaeva, R. Y. Yukhanov, and V. V. Rozhanets (1983) Content of DSIP, enkephalins and ACTH in some tissues of active and hibernating ground squirrels (Citellus suslicus). Comp. Biochem. Physiol. 74C: 31-33.

Marsden, C. A., M. P. Brazell, and N. T. Maidment (1984) An introduction to in vivo voltammetry. In Measurement of Neurotransmitter Release, C. A. Marsden, ed., pp. 127-151, Wiley, Chichester, U.K.

Mefford, I. N. (1981) Application of high performance liquid chromatography with clectrochemical detection in neurochemical analysis: Measurement of catecholamines, serotonin, and metabolites in rat brain. J. Neurosci. Methods 3: 207-224.

Salzman, S. K., C. Llados-Eckman, and A. L. Beckman (1985) In vivo analysis of dopamine and its metabolites in the caudate nucleus during euthermia and hibernation. Brain Res. 343: 95-103.

Seeman, P. (1980) Brain dopamine receptors. Pharmacol. Rev. 32: 229-313.

Shtark, M. B. (1970) The brain of hibernating animals. NASA Technical Translation TTF-619. (Translation of Mozg Zimnespyashchekt, Nauka Press, Siberian Branch, Novosibrisk.)

South, F. E., J. E. Breazile, H. S. Dellman, and A. D. Fpperly (1969) Sleep, hibernation and hypothermia in the yellow-bellied marmot $(M$. flaviventris). In Depressed Metabolism, X. J. Musacchia and J. F. Saundcrs, cds., pp. 277-312, Elsevier, New York.

Strumwasser, F. (1959a) Thermoregulatory brain and behavioral mechanism during entrance into hibernation in the squirrel Citellus beecheyi. Am. J. Physiol. 196: 15-22.

Strumwasser, F. (1959b) Regulatory mechanisms, brain activity and behavior during deep hibernation in the squirrel, Citellus beecheyi, Am. J. Physiol. 196: 23-30.

Trugman, J. M., W. A. Geary II, and G. F. Wooten (1986) Localization of D-2 receptors to intrinsic striatal neurones by quantitative autoradiography. Nature 323: 267-269.

Usdin, T. B., I. Creese, and S. H. Snyder. (1980) Regulation by cations of $\left[{ }^{3} \mathrm{H}\right]$ spiperidol binding associated with dopamine receptors of rat brain. J. Neurochem. 34: 669-676.

Yonehara, N., and D. H. Clouet (1984) Effects of delta and $m u$ opiopeptides on the turnover and release of dopamine in rat striatum. J. Pharmacol. Exp. Ther. 231: 38-42. 